\title{
ANALISIS KESTABILAN MODEL PENYEBARAN PENGGUNA NARKOBA
}

\author{
GHEA RATU ANNISA, MAHDHIVAN SYAFWAN, RIRI LESTARI \\ Jurusan S1 Matematika, \\ Fakultas Matematika dan Ilmu Pengetahuan Alam, Universitas Andalas, \\ Kampus UNAND Limau Manis Padang, Indonesia. \\ email : mahdhivan@sci.unand.ac.id
}

Diterima 4 Agustus 2021 Direvisi 15 September $2021 \quad$ Dipublikasikan 21 Oktober 2021

\begin{abstract}
Abstrak. Penelitian ini menjelaskan tentang penurunan model penyebaran pengguna narkoba yang dirumuskan oleh White-Comiskey. Dari model tersebut dilakukan analisis kestabilan titik-titik kesetimbangan endemik. Hasil yang diperoleh menunjukkan bahwa kasus pengguna narkoba, dengan kriteria tertentu, akan tetap ada dengan jumlah yang cenderung konstan.

Kata Kunci: Model White-Comiskey, Titik Kesetimbangan Endemik, Analisis Kestabilan.
\end{abstract}

\section{Pendahuluan}

Narkoba merupakan singkatan dari narkotika, psikotropika, dan bahan adiktif lain [4]. Menurut Undang-Undang Republik Indonesia Nomor 22 Tahun 1997 Pasal 1, narkotika adalah zat atau obat yang berasal dari tanaman atau bukan tanaman, baik sintetis maupun semisintetis, yang dapat menyebabkan penurunan atau perubahan kesadaran, hilangnya rasa, mengurangi sampai hilangnya rasa nyeri, dan dapat menimbulkan ketergantungan [1].

Kasus penyalahgunaan narkoba di Indonesia sudah menyebar di berbagai kalangan masyarakat, baik pada usia dewasa, remaja maupun usia anak-anak. Kondisi seperti ini tentunya sangat meresahkan dan merugikan bagi masa depan generasi penerus bangsa. Tidak hanya kecanduan, efek samping dari penyalahgunaan bahan berbahaya ini apabila dikonsumsi dalam dosis yang tinggi dapat berujung pada kematian.

Kecanduan narkoba tentu saja dapat diobati melalui program rehabilitasi yang disediakan bagi pengguna narkoba. Namun, program tersebut membutuhkan biaya yang sangat besar dan menjadi beban yang berat dalam sistem kesehatan negara. Kepala Urusan Rumah Tangga Balai Rehabilitasi Penyalahgunaan Narkoba,

*penulis korespondensi 
Lembaga Rehabilitasi Pencegahan Penyalahgunaan Narkoba (LRPPN) mengatakan bahwa rehabilitasi standar bagi pecandu narkoba membutuhkan dana sekitar Rp20an juta per orang [6].

Berdasarkan penjelasan di atas, maka perlu dibuat pemodelan matematika yang dapat menggambarkan penyebaran pengguna narkoba. Model matematika penyebaran pengguna narkoba diformulasi pertama kali oleh White-Comiskey pada tahun 2007 [5]. Ada tiga pembagian kelompok dalam model White-Comiskey, yaitu kelompok individu yang rentan menjadi pengguna narkoba, kelompok pengguna narkoba yang tidak dalam masa rehabilitasi dan kelompok pengguna narkoba yang dalam masa rehabilitasi. Pendekatan yang digunakan pada model ini adalah pendekatan model epidemik SIRS ( Susceptible - Infected - Removed - Susceptible), yaitu individu yang telah berhenti memakai narkoba dapat berkemungkinan kembali menjadi pecandu. Setelah pemodelan matematika dibuat, selanjutnya akan dianalisa kestabilan titik kesetimbangan endemik dari model White-Comiskey tersebut.

\section{Model Epidemik SIRS}

Model epidemik SIRS (Susceptible - Infected - Removered - Susceptible) merupakan pengembangan dari model epidemiologi yang pertama kali diperkenalkan oleh Kermack dan McKendric pada tahun 1927 [2]. Model ini terbagi menjadi tiga kelompok, yaitu :

(1) Susceptible $(S)$, yaitu kelompok individu yang masih sehat namun rentan terinfeksi penyakit.

(2) Infected $(I)$, yaitu kelompok individu yang sudah terinfeksi dan dapat menularkan penyakit ke susceptible apabila melakukan kontak dengannya, namun individu ini masih dapat sembuh dari penyakit.

(3) Removed $(R)$, yaitu kelompok individu yang telah sembuh dari penyakit dan dapat menjadi susceptible kembali.

Diagram model SIRS diperlihatkan dalam Gambar 1.

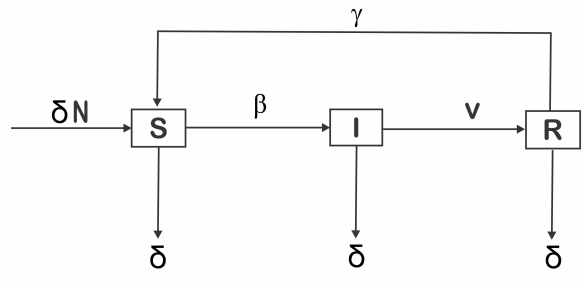

Gambar 1. Diagram Model SIRS

Parameter-parameter yang digunakan pada model SIRS yaitu [3] :

(i) $\gamma$ menyatakan tingkat populasi yang rentan kembali terkena penyakit.

(ii) $\delta$ menyatakan tingkat kelahiran atau kematian populasi, 
(iii) $\beta$ menyatakan tingkat penyebaran virus,

(iv) $v$ menyatakan tingkat populasi yang sembuh.

Berdasarkan Gambar 1, individu yang rentan terinfeksi penyakit dapat menjadi terinfeksi setelah melakukan kontak dengan individu terinfeksi. Selanjutnya, individu yang telah terinfeksi oleh penyakit dapat sembuh melalui sebuah pengobatan, dan yang sudah sembuh dapat kembali menjadi rentan terinfeksi.

\section{Formulasi Model Penyebaran Pengguna Narkoba}

Model penyebaran pengguna narkoba diformulasikan pertama kali oleh WhiteComiskey pada tahun 2007 [5] berdasarkan model SIRS. Hal ini karena ketergantungan narkoba dapat dianggap sebagai sebuah penyakit yang dapat menular ke individu lain. Populasi dalam model White-Comiskey ini dibagi menjadi tiga kelompok subpopulasi :

(1) Kelompok individu yang sehat namun rentan menjadi pengguna narkoba. Banyaknya individu dalam kelompok ini pada waktu $t$ dinotasikan dengan $S(t)$.

(2) Kelompok pengguna narkoba yang tidak dalam masa rehabilitasi dan dapat menginfeksi individu lain (yaitu menjadikan individu lain pengguna narkoba) ketika melakukan interaksi. Banyaknya individu dalam kelompok ini pada waktu $t$ dinotasikan dengan $U_{1}(\mathrm{t})$.

(3) Kelompok pengguna narkoba yang dalam masa rehabilitasi dan berpotensi menjadi pengguna narkoba kembali ketika berinteraksi dengan pengguna narkoba yang tidak dalam masa rehabilitasi. Banyaknya individu dalam kelompok ini pada waktu $t$ dinotasikan dengan $U_{2}(\mathrm{t})$.

Total populasi keseluruhan dari jumlah kelompok subpopulasi tersebut dinotasikan dengan $N$ dan dianggap konstan, yaitu

$$
N=S(t)+U_{1}(t)+U_{2}(t)
$$

Sebelum model penyebaran pengguna narkoba diformulasikan, terlebih dahulu dikonstruksi diagram model penyebaran pengguna narkoba dengan menggunakan diagram model SIRS. Hasil konstruksi diagram yang dimaksud diberikan pada Gambar 2 .

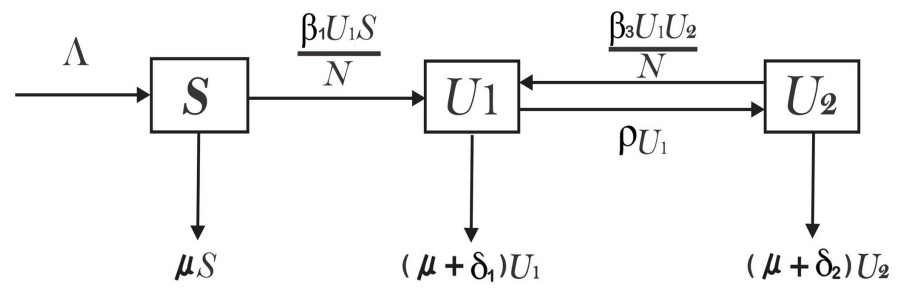

Gambar 2. Diagram Model Penyebaran Pengguna Narkoba. 
Berikut adalah penjelasan parameter-parameter yang terdapat pada diagram model penyebaran pengguna narkoba :

(1) $\beta_{1}$ : peluang individu menjadi pengguna narkoba

(2) $\beta_{3}$ : peluang pengguna narkoba dalam masa rehabilitasi yang kembali menggunakan narkoba

(3) $\rho$ : proporsi pengguna narkoba yang masuk masa rehabilitasi

(4) $\mu$ : laju kematian alami dari populasi (per satuan waktu)

(5) $\delta_{1}$ : laju kematian pengguna narkoba yang tidak dalam masa rehabilitasi (per satuan waktu)

(6) $\delta_{2}$ : laju kematian pengguna narkoba dalam masa rehabilitasi (per satuan waktu)

(7) $\Lambda$ : jumlah individu yang memasuki populasi rentan.

Semua parameter di atas ditetapkan bernilai positif.

Ada beberapa asumsi yang digunakan pada model penyebaran penggunaan narkoba ini, yaitu :

(1) Populasi tidak mengalami proses migrasi atau bersifat tertutup.

(2) Total populasi $N$ dianggap konstan sehingga berlaku

$$
\Lambda=\mu S+\left(\mu+\delta_{1}\right) U_{1}+\left(\mu+\delta_{2}\right) U_{2} .
$$

Berdasarkan persamaan (3.2), jumlah individu yang memasuki populasi rentan (susceptible) sama dengan jumlah individu yang keluar di setiap kelompok karena kematian. Kematian tersebut diakibatkan karena kematian alami maupun penggunaan narkoba.

(3) Individu yang rentan menggunakan narkoba maupun pengguna narkoba yang dalam masa rehabilitasi dapat terinfeksi apabila melakukan kontak dengan pengguna narkoba yang tidak dalam masa rehabilitasi.

(4) Ada suatu proporsi pengguna narkoba yang masuk masa rehabilitasi.

(5) Seluruh individu dalam populasi memiliki potensi rentan terhadap kecanduan narkoba.

(6) Pengguna narkoba yang dalam masa rehabilitasi tidak dapat menginfeksi individu yang rentan.

Beberapa hal yang dapat dijelaskan berdasarkan Gambar 2 adalah sebagai berikut:

(1) Laju individu yang rentan menjadi pengguna narkoba diformulasikan dengan

$$
\frac{d S}{d t}=\Lambda-\frac{\beta_{1} U_{1} S}{N}-\mu S
$$

Persamaan (3.3) menyatakan bahwa laju individu yang rentan menjadi pengguna narkoba sama dengan jumlah individu yang memasuki populasi rentan dikurangi dengan proporsi individu menjadi pengguna narkoba dan yang meninggal karena kematian alami. 
(2) Laju individu pengguna narkoba yang tidak dalam masa rehabilitasi diformulasikan dengan

$$
\frac{d U_{1}}{d t}=\frac{\beta_{1} U_{1} S}{N}-\rho U_{1}+\frac{\beta_{3} U_{1} U_{2}}{N}-\left(\mu+\delta_{1}\right) U_{1} .
$$

Persamaan (3.4) menyatakan bahwa laju individu pengguna narkoba yang tidak dalam masa rehabilitasi sama dengan proporsi individu rentan dan dalam masa rehabilitasi menjadi pengguna narkoba dikurangi dengan proporsi pengguna narkoba yang masuk masa rehabilitasi dan yang meninggak baik karena kematian alami maupun akibat penggunaan narkoba dalam masa di luar rehabilitasi.

(3) Laju individu pengguna narkoba yang dalam masa rehabilitasi diformulasikan dengan

$$
\frac{d U_{2}}{d t}=\rho U_{1}-\frac{\beta_{3} U_{1} U_{2}}{N}-\left(\mu+\delta_{2}\right) U_{2} .
$$

Persamaan (3.5) menyatakan bahwa laju individu pengguna narkoba yang dalam masa rehabilitasi sama dengan proporsi pengguna narkoba yang masuk masa rehabilitasi dikurangi proporsi pengguna narkoba yang dalam masa rehabilitasi kembali menggunakan narkoba yang meninggal baik karena kematian alami maupun akibat penggunaan narkoba dalam masa rehabilitasi.

Berdasarkan penjelasan di atas, maka penyebaran pengguna narkoba dapat dimodelkan oleh sistem persamaan diferensial biasa orde satu nonliner berikut:

$$
\begin{aligned}
\frac{d S}{d t} & =\Lambda-\frac{\beta_{1} U_{1} S}{N}-\mu S, \\
\frac{d U_{1}}{d t} & =\frac{\beta_{1} U_{1} S}{N}-\rho U_{1}+\frac{\beta_{3} U_{1} U_{2}}{N}-\left(\mu+\delta_{1}\right) U_{1}, \\
\frac{d U_{2}}{d t} & =\rho U_{1}-\frac{\beta_{3} U_{1} U_{2}}{N}-\left(\mu+\delta_{2}\right) U_{2} .
\end{aligned}
$$

\section{Analisis Kestabilan Model}

Teorema 4.1. Jika $\beta_{1}>\beta_{3}$ dan $\mu+\delta_{2}<1$, maka titik kesetimbangan endemik $E^{*}$ stabil asimtotik.

Bukti. Perhatikan matriks Jacobian dari sistem (3.6) berikut :

$$
\begin{aligned}
J\left(S, U_{1}, U_{2}\right) & =\left(\begin{array}{ccc}
\frac{\partial f_{1}\left(S, U_{1}, U_{2}\right)}{\partial S} & \frac{\partial f_{1}\left(S, U_{1}, U_{2}\right)}{\partial U_{1}} & \frac{\partial f_{1}\left(S, U_{1}, U_{2}\right)}{\partial U_{2}} \\
\frac{\partial f_{2}\left(S, U_{1}, U_{2}\right)}{\partial S} & \frac{\partial f_{2}\left(S, U_{1}, U_{2}\right)}{\partial U_{2}} & \frac{\partial f_{2}\left(S, U_{1}, U_{2}\right)}{\partial U_{1}} \\
\frac{\partial f_{3}\left(S, U_{1}, U_{2}\right)}{\partial S} & \frac{\partial f_{3}\left(S, U_{1}, U_{2}\right)}{\partial U_{2}} & \frac{\partial f_{3}\left(S, U_{1}, U_{2}\right)}{\partial U_{2}}
\end{array}\right) \\
= & \left(\begin{array}{ccc}
\frac{-\beta_{1} U_{1}}{N}-\mu & \frac{-\beta_{1} S}{N} & 0 \\
\frac{\beta_{1} U_{1}}{N} & \frac{\beta_{1} S}{N}-\rho+\frac{\beta_{3} U_{2}}{N}-\mu-\delta_{1} & \frac{\beta_{3} U_{1}}{N} \\
0 & \rho-\frac{\beta_{3} U_{2}}{N} & \frac{-\beta_{3} U 1}{N}-\mu-\delta_{2}
\end{array}\right) .
\end{aligned}
$$


Kestabilan sistem (3.6) di sekitar titik kesetimbangan endemik $E^{*}$ dapat ditentukan dengan terlebih dahulu mensubstitusikan nilai $S^{*}=\frac{\Lambda N}{N \mu+W \beta_{1}}, U_{1}^{*}=W$, $\operatorname{dan} U_{2}^{*}=\frac{\left(-\beta_{1} \Lambda+\rho \beta_{1} W+\rho \mu N+\mu \beta_{1} W+\mu^{2} N+\delta_{1} \beta_{1} W+\delta_{1} \mu N\right) N}{\left(\beta_{1} W+\mu N\right) \beta_{3}}$ ke matriks Jacobian (4.1), diperoleh

$$
J\left(S^{*}, U_{1}^{*}, U_{2}^{*}\right)=\left(\begin{array}{ccc}
\frac{-\beta_{1} W}{N}-\mu \frac{-\beta_{1} \Lambda}{N \mu+W \beta_{1}} & 0 \\
\frac{\beta_{1} W}{N} & C & \frac{\beta_{3} W}{N} \\
0 & D & \frac{-\beta_{3} W}{N}-\mu-\delta_{2}
\end{array}\right),
$$

dimana

$$
\begin{aligned}
C= & \frac{\beta_{1} \Lambda}{N \mu+W \beta_{1}}-\rho+\frac{N \mu^{2}+N \mu \rho+N \mu \delta_{1}+W \mu \beta_{1}+W \rho \beta_{1}+W \beta_{1} \delta_{1}-\Lambda \beta_{1}}{N \mu+W \beta_{1}}, \\
& -\mu-\delta_{1}, \\
D= & \rho-\frac{N \mu^{2}+N \mu \rho+N \mu \delta_{1}+W \mu \beta_{1}+W \rho \beta_{1}+W \beta_{1} \delta_{1}-\Lambda \beta_{1}}{N \mu+W \beta_{1}} .
\end{aligned}
$$

Selanjutnya, perhitungan untuk mendapatkan persamaan karakteristik dari matriks Jacobian (4.2) dapat dilakukan sebagai berikut :

$$
\begin{aligned}
& \left|J\left(S^{*}, U_{1}^{*}, U_{2}^{*}\right)-\lambda I\right|=0 \\
& \left|\left(\begin{array}{ccc}
\frac{-\beta_{1} W}{N}-\mu \frac{-\beta_{1} \Lambda}{N \mu+W \beta_{1}} & 0 \\
\frac{\beta_{1} W}{N} & C & \frac{\beta_{3} W}{N} \\
0 & D & \frac{-\beta_{3} W}{N}-\mu-\delta_{2}
\end{array}\right)-\left(\begin{array}{lll}
\lambda & 0 & 0 \\
0 & \lambda & 0 \\
0 & 0 & \lambda
\end{array}\right)\right|=0
\end{aligned}
$$

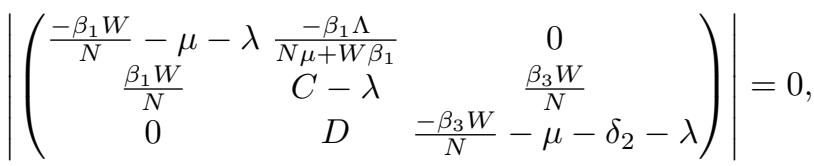

dan diperoleh

$$
\begin{gathered}
\lambda^{3}+\frac{\left(2 N \mu+N \delta_{2}+W \beta_{1}+W \beta_{3}\right) \lambda^{2}}{N}+\frac{1}{N^{2}\left(N \mu+W \beta_{1}\right)}\left(N^{3} \mu^{3}+N^{3} \mu^{2} \delta_{2}+2 N^{2} W\right. \\
\mu^{2} \beta_{1}+2 N^{2} W \mu^{2} \beta_{3}+2 N^{2} W \mu \beta_{1} \delta_{2}+N^{2} W \mu \beta_{3} \delta_{1}+N W^{2} \mu \beta_{1}^{2}+3 N W^{2} \mu \beta_{1} \beta_{3}+N \\
\left.W^{2} \beta_{1}^{2} \delta_{2}+N W^{2} \beta_{1} \beta_{3} \delta_{1}+W^{3} \beta_{1}^{2} \beta_{3}+\Lambda N W \beta_{1}^{2}-\Lambda N W \beta_{1} \beta_{3}\right) \lambda+\frac{1}{N^{2}\left(N \mu+W \beta_{1}\right)} \\
\left(N^{2} W \mu^{3} \beta_{3}+N^{2} W \mu^{2} \beta_{3} \delta_{1}+2 N W^{2} \mu^{2} \beta_{1} \beta_{3}+2 N W^{2} \mu \beta_{1} \beta_{3} \delta_{1}+W^{3} \mu \beta_{1}^{2} \beta_{3}+W^{3} \beta_{1}^{2}\right. \\
\left.\beta_{3} \delta_{1}+\Lambda N W \mu \beta_{1}^{2}-\Lambda N W \mu \beta_{1} \beta_{3}+\Lambda N W \beta_{1}^{2} \delta_{2}\right)=0 .
\end{gathered}
$$

Dari persamaan karakteristik (4.2), jelas terlihat bahwa koefisien dari $\lambda^{3}$ dan $\lambda^{2}$ bernilai positif. Namun koefisien $\lambda$ dan konstanta suku ke-empat belum dapat dipastikan apakah bernilai positif atau negatif. Agar titik kesetimbangan endemik $\mathrm{E}^{*}$ stabil asimtotik, maka akar dari persamaan karakteristik (4.2) (nilai-nilai eigen 
ג) haruslah bernilai riil negatif. Berdasarkan Kriteria Routh-Hurwitz, untuk mendapatkan akar persamaan karakteristik (4.2) bernilai riil negatif haruslah

$$
\left|a_{1}\right|>0
$$

dan

$$
M\left(S^{*}, U_{1}^{*}, U_{2}^{*}\right)=\left|\begin{array}{cc}
a_{1} & a_{3} \\
1 & a_{2}
\end{array}\right|>0
$$

dimana

$$
\begin{aligned}
a_{1}= & \frac{2 N \mu+N \delta_{2}+W \beta_{1}+W \beta_{3}}{N}, \\
a_{2}= & \frac{1}{N^{2}\left(N \mu+W \beta_{1}\right)}\left(N^{3} \mu^{3}+N^{3} \mu^{2} \delta_{2}+2 N^{2} W \mu^{2} \beta_{1}+2 N^{2} W \mu^{2} \beta_{3}+2 N^{2} W \mu \beta_{1} \delta_{2}\right. \\
& +N^{2} W \mu \beta_{3} \delta_{1}+N W^{2} \mu \beta_{1}^{2}+3 N W^{2} \mu \beta_{1} \beta_{3}+N W^{2} \beta_{1}^{2} \delta_{2}+N W^{2} \beta_{1} \beta_{3} \delta_{1}+W^{3} \beta_{1}^{2} \\
& \left.\beta_{3}+\Lambda N W \beta_{1}^{2}-\Lambda N W \beta_{1} \beta_{3}\right), \\
a_{3}= & \frac{1}{N^{2}\left(N \mu+W \beta_{1}\right)}\left(W \left(N^{2} \mu^{3} \beta_{3}+N^{2} \mu^{2} \beta_{3} \delta_{1}+2 N W \mu^{2} \beta_{1} \beta_{3}+2 N W \mu \beta_{1} \beta_{3} \delta_{1}+\right.\right. \\
& \left.\left.W^{2} \mu \beta_{1}^{2} \beta_{3}+W^{2} \beta_{1}^{2} \beta_{3} \delta_{1}+\Lambda N \mu \beta_{1}^{2}-\Lambda N \mu \beta_{1} \beta_{3}+\Lambda N \beta_{1}^{2} \delta_{2}\right)\right) .
\end{aligned}
$$

Dari pertidaksamaan (4.4), diperoleh

$$
\begin{aligned}
& \frac{1}{N^{3}\left(N \mu+W \beta_{1}\right)}\left(2 N^{4} \mu^{4}+3 N^{4} \mu^{3} \delta_{2}+N^{4} \mu^{2} \delta_{2}^{2}+5 N^{3} W \mu^{3} \beta_{1}+4 N^{3} W \mu^{3} \beta_{3}+7 N^{3}\right. \\
& W \mu^{2} \beta_{1} \delta_{2}+N^{3} W \mu^{2} \beta_{3} \delta_{1}+3 N^{3} W \mu^{2} \beta_{3} \delta_{2}+2 N^{3} W \mu \beta_{1} \delta_{2}^{2}+N^{3} W \mu \beta_{3} \delta_{1} \delta_{2}+4 N^{2} W^{2} \\
& \mu^{2} \beta_{1}^{2}+8 N^{2} W^{2} \mu^{2} \beta_{1} \beta_{3}+2 N^{2} W^{2} \mu^{2} \beta_{3}^{2}+5 N^{2} W^{2} \mu \beta_{1}^{2} \delta_{2}+N^{2} W^{2} \mu \beta_{1} \beta_{3} \delta_{1}+5 N^{2} W^{2} \\
& \mu \beta_{1} \beta_{3} \delta_{2}+N^{2} W^{2} \mu \beta_{3}^{2} \delta_{1}+N^{2} W^{2} \beta_{1}^{2} \delta_{2}^{2}+N^{2} W^{2} \beta_{1} \beta_{3} \delta_{1} \delta_{2}+N W^{3} \mu \beta_{1}^{3}+5 N W^{3} \mu \beta_{1}^{2} \\
& \beta_{3}+3 N W^{3} \mu \beta_{1} \beta_{3}^{2}+N W^{3} \beta_{1}^{3} \delta_{2}+2 N W^{3} \beta_{1}^{2} \beta_{3} \delta_{2}+N W^{3} \beta_{1} \beta_{3}^{2} \delta_{1}+W^{4} \beta_{1}^{3} \beta_{3}+W^{4} \beta_{1}^{2} \\
& \left.\beta_{3}^{2}+\Lambda N^{2} W \mu \beta_{1}^{2}-\Lambda N^{2} W \mu \beta_{1} \beta_{3}-\Lambda N^{2} W \beta_{1} \beta_{3} \delta_{2}+\Lambda N W^{2} \beta_{1}^{3}-\Lambda N W^{2} \beta_{1} \beta_{3}^{2}\right)>0 .
\end{aligned}
$$

Jelas bahwa pertidaksamaan di atas berlaku jika

$$
\beta_{1}>\beta_{3}
$$

dan

$$
\mu+\delta_{2}<1
$$

Dengan demikian jika $\beta_{1}>\beta_{3}$ dan $\mu+\delta_{2}<1$, maka nilai-nilai eigen $\lambda$ bernilai riil negatif. Akibatnya titik kesetimbangan endemik $E^{*}$ stabil asimtotik.

Interpretasi: Dari Teorema 4.1 dapat disimpulkan bahwa jika peluang individu rentan menjadi pengguna narkoba lebih besar daripada peluang pengguna narkoba yang dalam masa rehabilitasi kembali menggunakan narkoba, dan total laju kematian baik karena faktor alami maupun akibat penggunaan narkoba dalam masa rehabilitasi lebih kecil daripada 1, maka kasus pengguna narkoba akan tetap ada dengan jumlah yang cenderung konstan. 


\section{Kesimpulan}

Berdasarkan analisis kestabilan pada penelitian ini diperoleh hasil bahwa titik kesetimbangan endemik $E^{*}$ stabil asimtotik jika peluang individu rentan menjadi pengguna narkoba lebih besar daripada peluang pengguna narkoba yang dalam masa rehabilitasi kembali menggunakan narkoba, dan total laju kematian baik karena faktor alami maupun akibat penggunaan narkoba dalam masa rehabilitasi lebih kecil daripada 1.

\section{Ucapan Terima kasih}

Penulis mengucapkan terima kasih kepada bapak Prof. Dr. Muhafzan, bapak Narwen, M.Si dan bapak Budi Rudianto, M.Si yang telah memberikan masukan dan saran sehingga jurnal ini dapat diselesaikan dengan baik.

\section{Daftar Pustaka}

[1] Badan Narkotika Nasional, [PKKUI] Pusat Penelitian Kesehatan Universitas Indonesia. 2016. Hasil Survei Penyalahgunaan dan Peredaran Gelap Narkoba Pada Kelompok Pelajar dan Mahasiswa di 18 Provinsi Tahun 2016.

[2] Keshet, L. 1988. Matematical Models in Biology. Random House, New York.

[3] Lestari, R. 2012. Pengembangan Model Penyebaran Pengguna Narkoba WhiteComiskey. Tesis S-2, tidak diterbitkan. Institut Pertanian Bogor, Bogor.

[4] Riadi, M. 2013. Pengertian dan jenis-jenis napza. http://www.kajianpustaka. com/2013/08/pengertian-dan-jenis-jenis-napza.html? $\mathrm{m}=1$, diakses tanggal 5 Maret 2019 pukul 22.00 WIB.

[5] White, E. and Comiskey, C. 2006. Heroin epidemics, treatment and ODE modelling. Matematical Biosciences. 208: 312-324.

[6] Winata, R. 2018. Biaya rehabilitasi narkoba beikisar Rp 20 juta. http://www.medanbisnisdaily.com/news/read/2018/02/28/338941/biayarehabilitasi-narkoba-berkisar-rp-20juta, diakses tanggal 27 Juni 2019 pukul 13.00 WIB. 